\title{
Guidelines for fertilizer use in vineyards based on nutrient content of grapevine parts
}

\author{
Margarida Arrobas*, Isabel Q. Ferreira, Sara Freitas, João Verdial, M. Ângelo Rodrigues \\ Mountain Research Centre (CIMO), Polytechnic Institute of Bragança, Ap 1172, 5301-855 Bragança, Portugal
}

\section{A R T I C L E I N F O}

\section{Article history:}

Received 23 January 2014

Received in revised form 14 April 2014

Accepted 16 April 2014

Available online 4 May 2014

\section{Keywords:}

Vitis vinifera

Tissue nutrient concentration

Tissue nutrient content

Fertilizer recommendation

\begin{abstract}
A B S T R A C T
Plant analysis plays a major role in fertilizer recommendations for perennial tree crops and vines. Plant analysis, however, does not quantify the rate of nutrients to apply. The approach developed in this work takes into account the content of the nutrients in grapevine parts and their dynamic within the plant to assist in the estimation of the amount of fertilizer to apply. Groups of three vines were cut at ground level on four different dates from September 14th to November 28th. On the first sampling date the vines were separated into trunk, cordons, canes, leaves and clusters for determination of dry matter content and elemental composition. On the following dates the vines were separated into the plant parts that were still present, since the clusters were only present on the first sampling date and the leaves on the first two. To assess the mobility of nutrients within the plant, samples of phloem vessels and sawdust of the entire trunk were taken as well as samples of chlorotic and green leaves. Nitrogen (N), potassium $(\mathrm{K})$, phosphorus $(\mathrm{P})$ and boron $(\mathrm{B})$ showed mobility within the plant whereas calcium $(\mathrm{Ca})$ and magnesium $(\mathrm{Mg})$ did not. The removal of nutrients in clusters is critical for estimating $\mathrm{N}$ and $\mathrm{K}$ fertilizer rates. Clusters removed $19.9 \mathrm{~kg} \mathrm{~N} \mathrm{ha}^{-1}$ and $28.7 \mathrm{~kg} \mathrm{Kha}^{-1}$. In the case of $\mathrm{N}$, it is also important to assess the system's ability to recycle the nutrient contained in the leaves and canes which amounted to $49.4 \mathrm{~kg} \mathrm{~N} \mathrm{ha}^{-1}$. Phosphorus, calcium and magnesium applications might not justify being taken into account in the annual fertilization plan. Thus, the establishment of the fertilization programme should be a nutrient-specific exercise which takes into account all sources of information, including target yield and nutrient content in clusters, the vineyard management strategies influencing nutrient use efficiency from fallen leaves and prunings and soil testing and plant analysis.
\end{abstract}

(ㄷ) 2014 Elsevier B.V. All rights reserved.

\section{Introduction}

Adequate nutrition is essential for the growth and yield of grapevines as for any crop. Nitrogen is the major nutrient affecting grapevine vigour and must quality (Brunetto et al., 2007; Akin et al., 2012; Pérez-Álvarez et al., 2013). The addition of $\mathrm{K}$ can increases grape yield, as the result of increased cluster number and weight (Amiri and Fallahi, 2007). A strong correlation between $\mathrm{K}$ grapevine nutritional status and must attributes has also been observed. Excess $\mathrm{K}$ levels in grape berries can result in a high juice $\mathrm{pH}$, with a detrimental impact on wine quality (Mpelasoka et al., 2003; Fogaça et al., 2007; Assimakopoulou and Tsougrianis, 2012; Cuéllar et al., 2013).

\footnotetext{
* Corresponding author. Tel.: +351 273303255; fax: +351 273425675

E-mail address: marrobas@ipb.pt (M. Arrobas).
}

In vines, as in other crops, any excess of fertilizer use must be avoided. The price of fertilizers has increased, particularly those containing $\mathrm{N}$ and $\mathrm{P}$. The price of $\mathrm{N}$ has been directly influenced by the increase the price of crude oil, and the price of $P$ has reflected the price instability associated the finite supply of phosphate rocks from which P fertilizers are obtained (Smil, 2001; Gilbert, 2009). It should also be stressed the environmental impact potentially associated to the excessive use of fertilisers, particularly of those containing N (Powlson, 1993).

Soil analysis has been routinely used to assess soil conditions for plant growth and the need for supplemental fertilizers (Havlin et al., 2005). Chemical soil analysis indicates the potential availability of some nutrients that roots may take up under conditions favourable for plant growth (Römheld, 2012). Soil analysis can also be informative concerning possible toxicities of salt and boron. Soil $\mathrm{pH}$ can also be useful in predicting mineral nutritional problems. In spite of the importance of soil analysis in the fertilizer recommendation programmes for annual crops, it has lost favour over the 
Table 1

Selected soil properties in September 2012 in the $0-20 \mathrm{~cm}$ soil layer.

\begin{tabular}{lc}
\hline Soil properties & \\
\hline Sand (\%) & 62.7 \\
Silt (\%) & 19.5 \\
Clay (\%) & 17.8 \\
Organic C (Walkley-Black) $\left(\mathrm{g} \mathrm{kg}^{-1}\right)$ & 1.4 \\
$\mathrm{pH}($ Soil:water, $1: 2.5)$ & 6.7 \\
Exchangeable bases & \\
$\mathrm{K}\left(\mathrm{Cmol}_{\mathrm{c}} \mathrm{kg}^{-1}\right)$ & 1.16 \\
$\mathrm{Na}\left(\mathrm{Cmol}_{\mathrm{c}} \mathrm{kg}^{-1}\right)$ & 0.15 \\
$\mathrm{Ca}\left(\mathrm{Cmol}_{\mathrm{c}} \mathrm{kg}^{-1}\right)$ & 7.51 \\
$\mathrm{Mg}\left(\mathrm{Cmol}_{\mathrm{c}} \mathrm{kg}^{-1}\right)$ & 4.79 \\
Exchangeable acidity $\left(\mathrm{Cmol}_{\mathrm{c}} \mathrm{kg}^{-1}\right)$ & 0.23 \\
Cation exchange capacity $\left(\mathrm{Cmol}_{\mathrm{c}} \mathrm{kg}^{-1}\right)$ & 13.85 \\
Extractable P $\left(\mathrm{mg} \mathrm{kg}^{-1}\right)^{\mathrm{b}}$ & 66 \\
Extractable K $\left(\mathrm{mg} \mathrm{kg}^{-1}\right)^{\mathrm{b}}$ & 196 \\
Extractable B $\left(\mathrm{mg} \mathrm{kg}^{-1}\right)^{\mathrm{c}}$ & 1.1
\end{tabular}

a Ammonium acetate, $\mathrm{pH}$ 7.
b Extracted by ammonium lactate plus acetic acid, buffered at pH 3.7.
c Boiling water and azomethine-H procedures.

years for perennial deep-rooted crops, such as fruit trees and vines, because of the difficulty in defining with sufficient accuracy the root zones from which deep-rooting plants take up most of their nutrients (Winkler et al., 1974; Römheld, 2012).

Plant analysis is often the most reliable method of assessing crop nutritional status, currently being the basis of the fertilizer recommendation programmes for tree crops and vines. Several studies have been done in order to establish the most appropriate tissue for analysis. Leaf blade and petiole have been the major competing ones (Brunetto et al., 2007; Assimakopoulov and Tsougrianis, 2012; Benito et al., 2013). Although the preference for petioles has been increasing, leaf blade analysis continues to be used. Several different sampling dates have also been used. The sampling date is of major importance, since tissue nutrient concentrations vary greatly during the growing season (Römheld, 2012). In vines, the most popular sampling dates are flowering and veraison (Winkler et al., 1974; Porro et al., 1995; Mullins et al., 2007; Benito et al., 2013). Other researchers consider the issue even more complex. According to Porro et al. (1995), the choice of the sampling time should be made according to the diagnostic purpose. Benito et al. (2013) proposed the use of different tissues and different sampling dates depending on the nutrient to be analyzed. In spite of the effort that has been made in the standardization of the process of sampling, studies have shown that nutrient concentrations in plant tissues frequently fall outside the ranges currently considered normal or adequate in published standards (Winkler et al., 1974; Davenport et al., 2012). The great variability in plant analysis results has led to the establishment of standards for local growing conditions (Porro et al., 2001; Davenport et al., 2012; García-Escudero et al., 2013), important commercial cultivars (Fallahi et al., 2005; García-Escudero et al., 2013), or even rootstock-scion combinations (Lehoczky and Kocsis, 1998). However, the major limitation of plant analysis technology is its inability to provide quantified rates of nutrients to be applied.

The results of plant analysis are usually interpreted by comparing actual data with previous established critical values or sufficiency ranges (Mills and Jones, 1996). In order to improve the accuracy of the diagnosis of the nutritional status of crops, other forms of interpretation have been developed. DRIS (Diagnosis and Recommendation Integrated System) has probably been the most popular. DRIS uses ratios of nutrients, which reduces the sensitivity of tissue analysis to plant age (Römheld, 2012). Martín et al. (2013) established preliminary DRIS norms for leaf blade and petioles of Tempranillo cultivar grafted on Richter-110, at both flowering and veraison, in La Rioga, Spain. In spite of DRIS having been developed by Beaufils in 1973, and norms for several crops having been established (Summer, 1997; Beverly et al., 1984; Goh and Malakouti, 1992) most laboratories have not yet adopted it. The major problem is the regional sensitivity of the norms (Mackay et al., 1987). The output is also not easy to manage. DRIS orders the element nutrients according to their degree of deficiency, but it does not provide information on the fertilizer rates to apply.

In summary, there has been abundant work using plant analysis as a means of monitoring plant nutritional status. However, the effort in the quantification of the rates of nutrients to apply to the crops has been markedly less. The approach here developed tries to define the magnitude of fertilizer rates to apply, by estimating the nutrients removed in clusters at harvest and taking into account the capability of the system to recycle the nutrients contained in the fallen leaves and prunings.

\section{Materials and methods}

\subsection{Experimental site}

The experiment took place in the Sta Apolónia farm in Bragança (41.797288-6.766033) North-eastern Portugal. The region benefits from a Mediterranean climate with some Atlantic influence. Mean annual temperature and annual precipitation are $12.3^{\circ} \mathrm{C}$ and $7583 \mathrm{~mm}$, respectively. The vineyard is planted in a eutric Cambisol loamy textured. Selected soil properties recorded at the beginning of the experiment are presented in Table 1.

The grapevines used in this study were randomly selected from a non-irrigated vineyard of cv. Viosinho Blanc grafted on Richter110. The cv. Viosinho had medium vigour, the clusters and berries are small and the pellicule is yellowish green. It is grown in Douro Valley in Port wine production and in other regions to produce table wine. The vineyard plantation dates from 1997. The vines were spaced at $2.5 \mathrm{~m}$ between rows and $1.4 \mathrm{~m}$ within rows ( $\sim 2860$ vines per hectare). The vineyard has been pruned as Guyot double, with an average crop load of 24 buds per vine. The shoots were supported by three horizontal wires placed at 60,90 and $120 \mathrm{~cm}$ height from the soil. The farmer managed the winter weeds by an application of a glyphosate based herbicide by March. The weeds emerging in the spring have usually been controlled by May using a cultivator. The fertilization made by the farmer usually includes the application of a compound NPK fertilizer at an approximate rate of $20 \mathrm{~kg}\left(\mathrm{~N}, \mathrm{P}_{2} \mathrm{O}_{5}\right.$, and $\mathrm{K}_{2} \mathrm{O}$ ) ha ${ }^{-1}$ localized in a narrow strip of $1 \mathrm{~m}$ wide along the row. To control fungus diseases, namely powdery mildew (Erisiphe necator) and/or downy mildew (Plasmopara viticola), the farmer sprayed fungicides, differing in the active ingredient and in the number of applications from one year to another, according to the regional advisory system for vine protection.

\subsection{Experimental set up and laboratory analysis}

At veraison, three samples of leaf petioles were taken from the leaves opposite to the clusters in the plot where the study will take place to assess the vine nutritional status at the standardized date of sampling. At that time, twelve grapevines of similar vigour were marked for further experimental use. The pre-selected vines were thereafter cut at the ground level in groups of three distributed over four different dates from harvest until the leaves have completely fallen (September 14th, October 16th, November 2nd, and November 28th).

On all of the four sampling dates, the perennial structure of the vines was divided into trunk and cordons. Samples of sawdust were recorded from the entire section of trunk and cordons, after removing the dead bark, by using a handsaw. The sawdust was thereafter dried at $70^{\circ} \mathrm{C}$ to be analyzed for elemental composition. Also from the trunk and the cordons, samples of the phloem vessels were 
obtained. The dead bark was firstly removed and thereafter thinner blades of less than $1 \mathrm{~mm}$ of phloem tissue were separated from the woody material (xylem) with a sharp knife. The samples of phloem vessels were also oven-dried at $70^{\circ} \mathrm{C}$ and ground. Additionally, intact portions of trunk and cordons were oven-dried at constant weight allowing estimating the dry matter percentage in those plant parts.

On the two first sampling dates the canes were divided into three parts (basal, middle and top) and the leaves were separated from the wood. Thereafter, leaves and wood of the three parts were weighed fresh. A subsample of each part was also weighed fresh being thereafter oven-dried at $70^{\circ} \mathrm{C}$ to determine the dry matter content of the plant tissues. The subsamples were thereafter ground. On the third and fourth sampling dates only the canes were prepared according as above. Few leaves were present on the vines at the third sampling date and none at all at the fourth sampling date.

The clusters were weighed on the first date of sampling. The clusters of each individual vine were cut and weighed fresh. The rachis was separated from the berries and the seeds removed from the berries. All these three components of the clusters (rachis, seeds, pulp plus pellicule) were weighed fresh. Rachis and seeds were oven-dried at $70^{\circ} \mathrm{C}$, weighed dry and ground and analyzed for elemental concentration. The pulp (plus pellicule) was analyzed for fresh. The remaining material was thereafter dried at the same temperature to allow estimation of its dry matter content.

On October 16th, three samples of 50 chlorotic and green leaves (blade + petiole) were collected from vines surrounding those that were marked to be uprooted. The chlorotic and the green leaves were collected from a similar position in the canopy from the basal part of the canes.

All the tissue samples above mentioned were analyzed for carbon, nitrogen, phosphorus, potassium, calcium, magnesium, boron, copper, zinc, iron and manganese concentrations. Tissue analyses were performed by Walkley-Black (C), Kjeldahl (N), colorimetry (B and $\mathrm{P}$ ), flame emission spectrometry $(\mathrm{K})$ and atomic absorption spectrophotometry ( $\mathrm{Ca}, \mathrm{Mg}, \mathrm{Cu}, \mathrm{Zn}$, Fe and $\mathrm{Mn}$ ) methods (Walinga et al., 1989).

\subsection{Statistical analysis}

For each sampling date three vines (three replicates) were uprooted. Three replicates were also taken when leaf petioles were collected at veraison to assess the initial vine nutritional status and when chlorotic and green leaves were sampled on October 16th. The standard deviation was the statistic used to show how much variation from the average exists.
Table 2

Nutrient concentration in leaf petioles (mean $\pm S D$ ) taken from the opposite leaves to the clusters at veraison.

\begin{tabular}{lrlr}
\hline \multicolumn{2}{l}{ Macronutrients $\left(\mathrm{g} \mathrm{kg}^{-1}\right)$} & \multicolumn{2}{l}{ Micronutrients $\left(\mathrm{mg} \mathrm{kg}^{-1}\right)$} \\
\hline Nitrogen & $7.9 \pm 0.9$ & Boron & $19.3 \pm 1.1$ \\
Phosphorus & $4.0 \pm 0.4$ & Iron & $69.4 \pm 7.5$ \\
Potassium & $10.9 \pm 0.6$ & Manganese & $45.7 \pm 6.1$ \\
Calcium & $25.7 \pm 2.8$ & Copper & $30.6 \pm 4.3$ \\
Magnesium & $8.7 \pm 0.6$ & Zinc & $32.8 \pm 5.1$ \\
\hline
\end{tabular}

\section{Results}

Calcium was the most concentrated nutrient in leaf petioles taken at veraison $\left(25.7 \mathrm{~g} \mathrm{~kg}^{-1}\right)$. Phosphorus was the macronutrient least abundant in leaf petioles with an average concentration of $4.0 \mathrm{~g} \mathrm{~kg}^{-1}$ (Table 2).

At harvest the leaves are the most concentrated tissues of the vine in $\mathrm{N}$, particularly the younger leaves of the top of the canes. Leaf $\mathrm{N}$ concentrations were $16.9,18.3$ and $19.6 \mathrm{~g} \mathrm{~kg}^{-1}$, respectively in basal, middle and top leaves of the canes (Table 3). A moderately high $\mathrm{N}$ concentration was also present in the seeds $\left(14.8 \mathrm{~g} \mathrm{~kg}^{-1}\right)$. The woody parts (trunk, cordons and canes), had $\mathrm{N}$ concentrations lower than $4 \mathrm{~g} \mathrm{~kg}^{-1}$. Pulp also showed low $\mathrm{N}$ concentrations $\left(4.5 \mathrm{~g} \mathrm{~kg}^{-1}\right)$ in comparison to the other tissues of the vine. Phosphorus appeared in high concentrations in the leaves, in particular in those of the basal part of the canes $\left(2.0 \mathrm{~g} \mathrm{~kg}^{-1}\right)$. Seeds $\left(1.9 \mathrm{~g} \mathrm{~kg}^{-1}\right)$ and rachis $\left(1.8 \mathrm{~g} \mathrm{~kg}^{-1}\right)$ are also tissues showing a high concentration of $\mathrm{P}$. Rachis showed a particularly high $\mathrm{K}$ concentration $\left(28.6 \mathrm{~g} \mathrm{~kg}^{-1}\right)$. In the pulp, $\mathrm{K}$ concentration is moderately high $\left(8.3 \mathrm{~g} \mathrm{~kg}^{-1}\right)$, whereas in the seeds it was particularly low $\left(2.4 \mathrm{~g} \mathrm{~kg}^{-1}\right)$. Leaves showed $\mathrm{K}$ concentrations varying from 7.6 to $10.2 \mathrm{~g} \mathrm{~kg}^{-1}$. In the woody parts, $\mathrm{K}$ concentration decreased from the least to the greater lignified tissues, varying from 7.3 to $3.0 \mathrm{~g} \mathrm{~kg}^{-1}$, respectively in the apex of the cane and in the trunk. Calcium and magnesium concentrations in vine tissues followed a similar trend. Calcium was present in a high concentration in the leaves, in particular in those at the base of the cane $\left(30.8 \mathrm{~g} \mathrm{~kg}^{-1}\right)$. Grape clusters had low Ca concentrations, particularly the pulp $\left(1.8 \mathrm{~g} \mathrm{~kg}^{-1}\right)$. Calcium concentrations in the woody parts varied from 5.0 to $7.3 \mathrm{~g} \mathrm{~kg}^{-1}$. Magnesium concentration in basal leaves was $6.4 \mathrm{~g} \mathrm{~kg}^{-1}$ and in the pulp $0.6 \mathrm{~g} \mathrm{~kg}^{-1}$. Boron appeared in high concentrations in the leaves, in particular in the younger ones $\left(19.5 \mathrm{mg} \mathrm{kg}^{-1}\right)$. However, B concentrations in the canes were also appreciable, varying from 16.6 to $19.1 \mathrm{mg} \mathrm{kg}^{-1}$. In grape clusters, B concentration did not significantly vary among the different tissues, with $10.2,11.7$ and $12.3 \mathrm{mg} \mathrm{kg}^{-1}$, respectively in pulp, seeds and rachis. The trunk

Table 3

Tissue nutrient concentrations (mean \pm SD) in the different plant parts of a grapevine sampled at harvest on September 14 th.

\begin{tabular}{|c|c|c|c|c|c|c|c|}
\hline & $\mathrm{C}$ & $\mathrm{N}$ & $\mathrm{P}$ & $\mathrm{K}$ & $\mathrm{Ca}$ & $\mathrm{Mg}$ & $\mathrm{B}\left(\mathrm{mg} \mathrm{kg}^{-1}\right)$ \\
\hline & \multicolumn{7}{|l|}{$\left(\mathrm{g} \mathrm{kg}^{-1}\right)$} \\
\hline \multicolumn{8}{|l|}{ Plant part } \\
\hline Trunk & $562.8 \pm 8.3$ & $2.7 \pm 0.2$ & $0.5 \pm 0.1$ & $3.0 \pm 0.4$ & $6.2 \pm 1.7$ & $1.6 \pm 0.1$ & $5.6 \pm 2.0$ \\
\hline Cordons & $563.0 \pm 4.8$ & $3.6 \pm 0.5$ & $0.6 \pm 0.2$ & $3.3 \pm 0.1$ & $7.3 \pm 1.7$ & $1.9 \pm 0.3$ & $8.4 \pm 0.2$ \\
\hline \multicolumn{8}{|l|}{ Cane } \\
\hline Basal & $569.8 \pm 3.1$ & $3.3 \pm 0.2$ & $0.7 \pm 0.0$ & $4.1 \pm 0.7$ & $5.0 \pm 0.7$ & $1.7 \pm 0.2$ & $16.8 \pm 1.2$ \\
\hline Middle & $567.5 \pm 1.9$ & $3.3 \pm 0.2$ & $0.7 \pm 0.0$ & $4.7 \pm 2.0$ & $5.9 \pm 0.7$ & $2.2 \pm 0.4$ & $16.6 \pm 0.2$ \\
\hline Top & $560.7 \pm 4.7$ & $4.0 \pm 0.4$ & $0.8 \pm 0.2$ & $7.3 \pm 1.5$ & $6.5 \pm 0.8$ & $2.9 \pm 1.0$ & $19.1 \pm 1.2$ \\
\hline \multicolumn{8}{|l|}{ Leaves } \\
\hline Basal & $501.6 \pm 3.4$ & $16.9 \pm 1.0$ & $2.0 \pm 0.3$ & $7.6 \pm 0.7$ & $30.8 \pm 2.0$ & $6.4 \pm 2.4$ & $17.7 \pm 2.2$ \\
\hline Middle & $513.3 \pm 3.2$ & $18.3 \pm 0.7$ & $1.7 \pm 0.3$ & $9.0 \pm 1.0$ & $22.9 \pm 2.3$ & $4.7 \pm 1.6$ & $18.7 \pm 2.3$ \\
\hline Top & $519.0 \pm 7.3$ & $19.6 \pm 0.9$ & $1.6 \pm 0.2$ & $10.2 \pm 2.4$ & $23.6 \pm 2.5$ & $5.0 \pm 1.4$ & $19.5 \pm 2.5$ \\
\hline \multicolumn{8}{|l|}{ Grape } \\
\hline Pulp & $543.7 \pm 9.9$ & $4.5 \pm 0.3$ & $0.8 \pm 0.0$ & $8.3 \pm 0.8$ & $1.8 \pm 0.2$ & $0.6 \pm 0.1$ & $10.2 \pm 6.2$ \\
\hline Seed & $571.7 \pm 2.4$ & $14.8 \pm 0.4$ & $1.9 \pm 0.4$ & $2.4 \pm 0.3$ & $5.5 \pm 0.5$ & $1.4 \pm 0.1$ & $11.7 \pm 0.8$ \\
\hline Rachis & $521.4 \pm 8.4$ & $9.1 \pm 1.4$ & $1.8 \pm 0.5$ & $28.6 \pm 5.5$ & $5.9 \pm 0.5$ & $1.4 \pm 0.4$ & $12.3 \pm 1.8$ \\
\hline
\end{tabular}


Table 4

Dry matter $(\mathrm{DM})$ and tissue nutrient content (mean \pm SD) of the different plant parts of a vine sampled at harvest time on September 14 th.

\begin{tabular}{|c|c|c|c|c|c|c|c|}
\hline \multirow[t]{2}{*}{ Plant part } & \multirow[t]{2}{*}{$\mathrm{DM}\left(\mathrm{Mg} \mathrm{ha}^{-1}\right)$} & $\mathrm{N}$ & $\mathrm{P}$ & K & $\mathrm{Ca}$ & $\mathrm{Mg}$ & \multirow[t]{2}{*}{$\mathrm{B}\left(\mathrm{g} \mathrm{ha}^{-1}\right)$} \\
\hline & & \multicolumn{5}{|l|}{$\left(\mathrm{kg} \mathrm{ha}^{-1}\right)$} & \\
\hline Trunks & $5.1 \pm 0.8$ & $14.3 \pm 3.6$ & $2.8 \pm 0.9$ & $15.5 \pm 2.8$ & $33.4 \pm 13.1$ & $8.4 \pm 0.9$ & $30.5 \pm 13.3$ \\
\hline Canes & $2.3 \pm 0.7$ & $7.7 \pm 2.2$ & $1.6 \pm 0.5$ & $10.8 \pm 0.7$ & $12.9 \pm 4.6$ & $4.8 \pm 0.8$ & $38.6 \pm 11.2$ \\
\hline Leaves & $2.2 \pm 0.4$ & $41.7 \pm 8.6$ & $3.8 \pm 1.2$ & $20.3 \pm 1.2$ & $55.9 \pm 15.7$ & $11.4 \pm 2.9$ & $41.7 \pm 4.7$ \\
\hline Clusters & $3.5 \pm 0.6$ & $19.9 \pm 3.7$ & $3.2 \pm 0.8$ & $28.7 \pm 2.1$ & $8.2 \pm 1.2$ & $2.5 \pm 0.4$ & $36.1 \pm 17.7$ \\
\hline Total & $13.0 \pm 2.4$ & $83.5 \pm 18.0$ & $11.4 \pm 3.3$ & $75.3 \pm 4.1$ & $100.4 \pm 33.5$ & $27.0 \pm 4.3$ & $146.8 \pm 29.2$ \\
\hline
\end{tabular}

showed the lowest B concentration (5.6 $\mathrm{mg} \mathrm{kg}^{-1}$ ) amongst all the tissues of the vine.

The aboveground part of the vines accounted for $13.1 \mathrm{Mg} \mathrm{ha}^{-1}$ dry matter (DM) at harvest (Table 4). The woody parts,

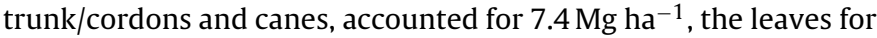
$2.2 \mathrm{Mg} \mathrm{ha}^{-1}$ and clusters for $3.5 \mathrm{Mg} \mathrm{ha}^{-1}$. The fresh weight of clusters was $14292 \mathrm{~kg} \mathrm{ha}^{-1}$. The total amounts of N, P, K, Ca, Mg and B that were found in the aboveground part of the vines were, respectively, 83.6, 11.4, 75.3, 100.4, $27.1 \mathrm{~kg} \mathrm{ha}^{-1}$ and $146.9 \mathrm{~g} \mathrm{ha}^{-1}$. Half of $\mathrm{N}$ in the plant was present in the leaves $\left(41.7 \mathrm{~kg} \mathrm{ha}^{-1}\right)$. The clusters also contained a significant amount of $\mathrm{N}\left(19.9 \mathrm{~kg} \mathrm{ha}^{-1}\right)$, whereas the woody parts contained only $14.3 \mathrm{~kg} \mathrm{ha}^{-1}$ (trunk and cordons) and $7.7 \mathrm{~kg} \mathrm{ha}^{-1}$ (canes). Phosphorus appeared more evenly distributed in all tissues than $\mathrm{N}$, although leaves $\left(3.8 \mathrm{~kg} \mathrm{ha}^{-1}\right)$ and clusters $\left(3.2 \mathrm{~kg} \mathrm{ha}^{-1}\right.$ ) contained the highest amounts. Potassium was present in significant amounts in all the aboveground parts of the vine. The clusters, however, contained the major portion $\left(28.7 \mathrm{~kg} \mathrm{Kha}^{-1}\right)$ followed by the leaves $\left(20.3 \mathrm{~kg} \mathrm{Kha}^{-1}\right)$. Calcium was the nutrient most abundant in the aboveground part of the vine. The leaves accounted for more than $50 \%$ of the nutrient. The clusters were a modest pool of Ca $\left(8.2 \mathrm{~kg} \mathrm{ha}^{-1}\right)$, whereas the woody plant parts contained relatively high amounts of the nutrient $\left(46.3 \mathrm{~kg} \mathrm{ha}^{-1}\right)$. The distribution of $\mathrm{Mg}$ in the vines was similar to that of calcium. In a total of $27.1 \mathrm{~kg} \mathrm{Mg} \mathrm{ha}^{-1}$, the leaves accounted for $11.4 \mathrm{~kg} \mathrm{ha}^{-1}$, the trunk/cordons plus canes for $13.2 \mathrm{~kg} \mathrm{ha}^{-1}$ and the clusters for $2.5 \mathrm{~kg} \mathrm{ha}^{-1}$. Boron also appeared evenly distributed between the aboveground parts of the vine. Leaves, canes, clusters and trunk/cordons contained respectively 41.7, 36.1, 38.6 and $30.5 \mathrm{~g} \mathrm{ha}^{-1}$

In only two of the four sampling dates (September 14th and October 16th), vines still had leaves. Leaf $\mathrm{N}$ concentration greatly decreased in the month, between the two sampling dates. The pattern was similar among the leaves of the different locations of the cane. In the middle part of the cane, for instance, leaf $\mathrm{N}$ concentration decreased from $18.3 \mathrm{~g} \mathrm{~kg}^{-1}$ to $13.3 \mathrm{~g} \mathrm{~kg}^{-1}$ (Fig. 1). Leaf $\mathrm{P}$ concentrations varied over time in a similar manner as $\mathrm{N}$. In the middle part of the cane, leaf $P$ concentration decreased from $1.7 \mathrm{~g} \mathrm{~kg}^{-1}$ to $1.2 \mathrm{~g} \mathrm{~kg}^{-1}$ between September 14 th and October 16 th. Leaf $\mathrm{K}$ concentration varied little from September 14th to October 16 th. Mean values were very close to $10 \mathrm{~g} \mathrm{~kg}^{-1}$. Leaf Ca concentrations greatly differed among the different parts of the cane in the sampling of September 14th. The higher values were found in the basal leaves $\left(30.8 \mathrm{~g} \mathrm{~kg}^{-1}\right)$. On October 16 th, all the three groups of leaves presented similar Ca concentrations, ranging from 24.2 to $26.2 \mathrm{~g} \mathrm{~kg}^{-1}$. Leaf $\mathrm{Mg}$ concentration presented a similar variation to that observed to Ca. In September the values ranged from 4.7 to $6.4 \mathrm{~g} \mathrm{~kg}^{-1}$ and in October from 4.8 to $5.7 \mathrm{~g} \mathrm{~kg}^{-1}$. Leaf B concentration decreased from September to October in all groups of leaves, as was observed for $\mathrm{N}$ and $\mathrm{P}$. The values in September ranged from 17.7 to $19.5 \mathrm{~g} \mathrm{~kg}^{-1}$ and in October from 17.1 to $17.6 \mathrm{~g} \mathrm{~kg}^{-1}$.

Chlorotic leaves showed a consistent decrease in $\mathrm{N}$ concentration in comparison to green leaves collected from the same vines. Nitrogen concentration in green leaves was $11.9 \mathrm{~g} \mathrm{~kg}^{-1}$ and in chlorotic leaves $6.2 \mathrm{~g} \mathrm{~kg}^{-1}$ (Table 5). Chlorotic leaves also showed
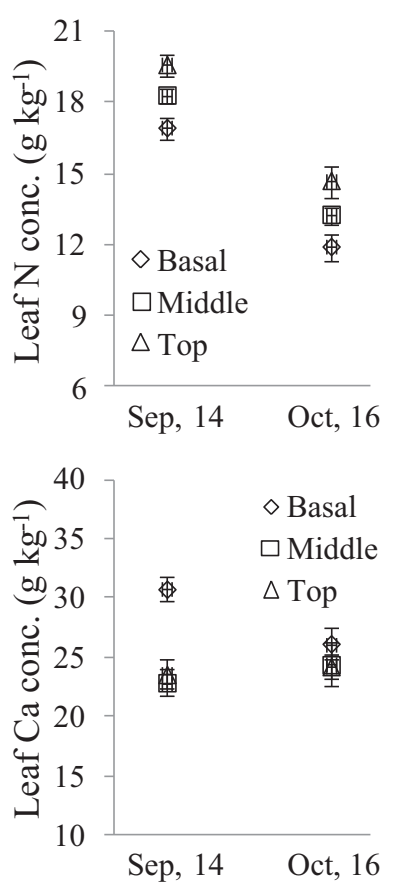
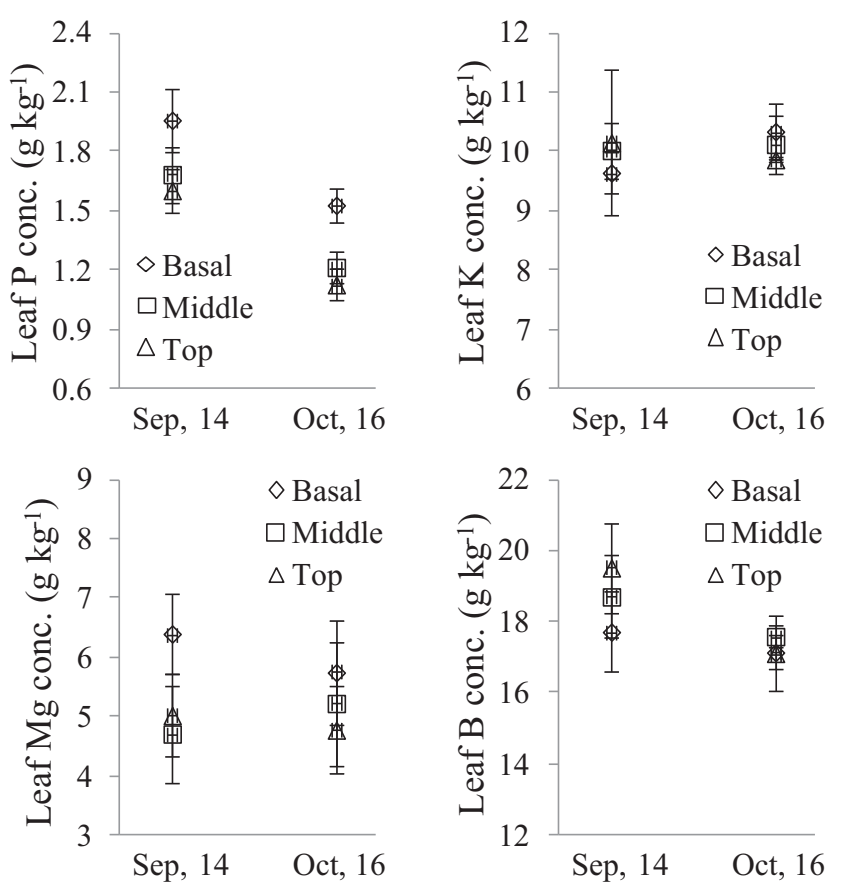

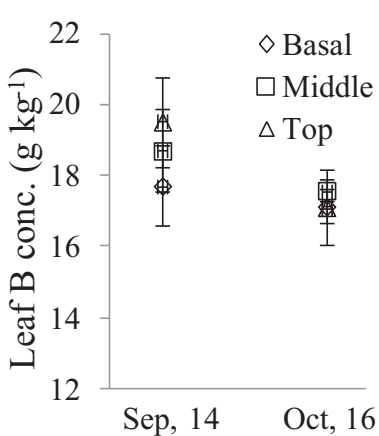

Fig. 1. Leaf nutrient concentrations in the three groups of trees (basal, middle and top) on September 14th (harvest) and October 16th. 
Table 5

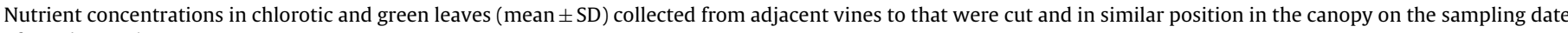
of October 16 th.

\begin{tabular}{|c|c|c|c|c|c|c|}
\hline \multirow[t]{2}{*}{ Leaves } & $\mathrm{N}$ & $\mathrm{P}$ & K & $\mathrm{Ca}$ & $\mathrm{Mg}$ & \multirow[t]{2}{*}{$\mathrm{B}\left(\mathrm{mg} \mathrm{kg}^{-1}\right)$} \\
\hline & \multicolumn{5}{|l|}{$\left(\mathrm{g} \mathrm{kg}^{-1}\right)$} & \\
\hline Green & $11.9 \pm 1.3$ & $1.5 \pm 0.2$ & $10.3 \pm 0.9$ & $26.2 \pm 2.6$ & $5.7 \pm 1.8$ & $18.1 \pm 1.0$ \\
\hline Chlorotic & $6.2 \pm 0.4$ & $1.4 \pm 0.4$ & $6.9 \pm 1.4$ & $31.2 \pm 3.6$ & $6.7 \pm 1.5$ & $20.1 \pm 1.3$ \\
\hline
\end{tabular}

low K concentrations compared with green leaves. Regarding leaf $\mathrm{P}$ concentrations, there was found to be a slight decrease as the leaves were getting chlorotic; for $\mathrm{Ca}, \mathrm{Mg}$ and $\mathrm{B}$ a slight increase was found.

Cane $\mathrm{N}$ concentrations increased over time from ripening until late November (Fig. 2). Regarding P, it seems that there was a decrease in nutrient concentrations between the sampling of September and October, and stabilization or a slight increase as the season progressed to the autumn. The concentration of $\mathrm{K}$ in canes followed an opposite pattern to P. Initially, from September 14th to October 16th, K concentrations increased and thereafter decreased until late November. Calcium, magnesium and boron showed little variation in canes from harvest until the end of November.

Wood (trunk and cordons) N concentrations slightly increased from September 14th to October 16th, remaining thereafter fairly constant (Fig. 3). Nitrogen concentrations in the phloem vessels were higher than those observed in the xylem. It seems that there was an increase in $N$ concentrations from September 14th to November 2nd, and thereafter a pronounced decrease, when all the leaves had fallen. Phosphorus concentrations in the wood did not significantly vary over time. However, in the phloem vessels the trend was similar to that in canes, first showing a decrease and thereafter an increase. Potassium concentrations in phloem vessels and wood presented a similar trend, first experiencing an increase and, on the last sampling dates, a decrease. Calcium and magnesium concentrations in phloem vessels were higher than those in wood. Boron concentrations increased from the first to the fourth sampling dates in the woody part and also in the phloem vessels. The increase in B concentrations in the woody part was probably due also to the presence of phloem tissues in the woody sample which included tissue from the entire trunk excluding the dead bark.

\section{Discussion}

In grapevines, it has been usual to find tissue nutrient concentrations outside the published standard ranges even in vineyards with apparent normal growth. However, the petiole nutrient concentrations at veraison here reported were not greatly dissimilar to those found in the literature (Mills and Jones, 1996; Fallahi et al., 2005; Davenport et al., 2012; García-Escudero et al., 2013), which suggested that the nutritional status of the vineyard used in this study is within the adequate range for the nutrients considered.

Leaves were the tissues of the highest $\mathrm{N}$ concentrations in the vines. The same was true for the other nutrients, $\mathrm{K}$ concentrations in rachis being the only exception. Nitrogen forms part of several cell constituents, such as proteins, nucleic acids and chlorophyll, which justifies its relative abundance in the leaves (Hawkesford et al., 2012). In this work, nutrient concentration was determined in the whole leaf (blade + petiole) from sub-samples including all the leaves of a cane section. As far as we know, there are no published data analyzing samples of whole vine leaves taken at harvest. Even so, recorded leaf nutrient concentrations are of the same order of magnitude as those found in the literature for blades of the leaves opposite to the cluster and taken at veraison (Davenport et al., 2012; García-Escudero et al., 2013). Previous studies have shown that grapes are the major sink for K after berry growth commences (Mpelasoka et al., 2003; Poni et al., 2003; Mullins et al., 2007). However, clusters contained the highest (rachis) and the lowest (seeds)
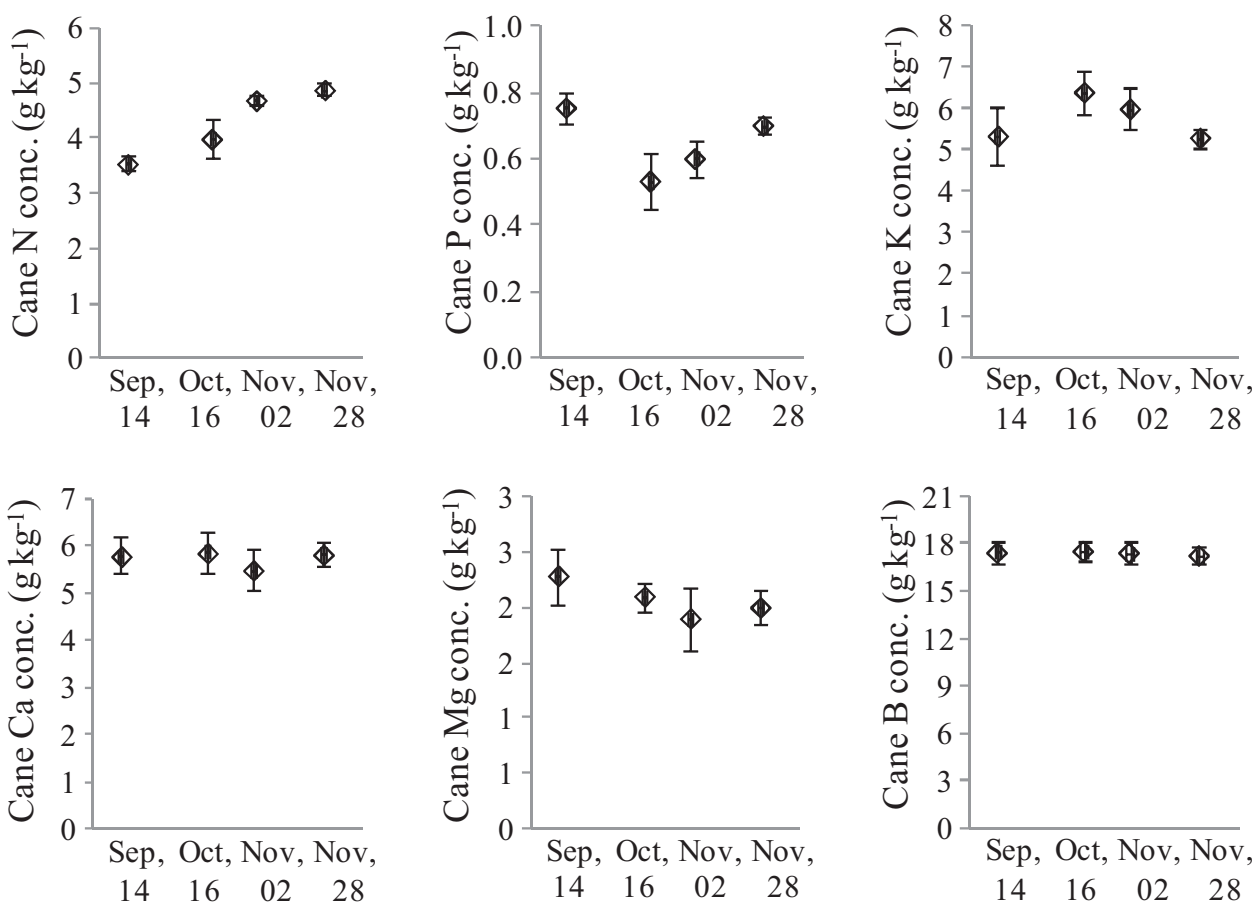

Fig. 2. Cane nutrient concentrations from September 14th (harvest) to late November. 

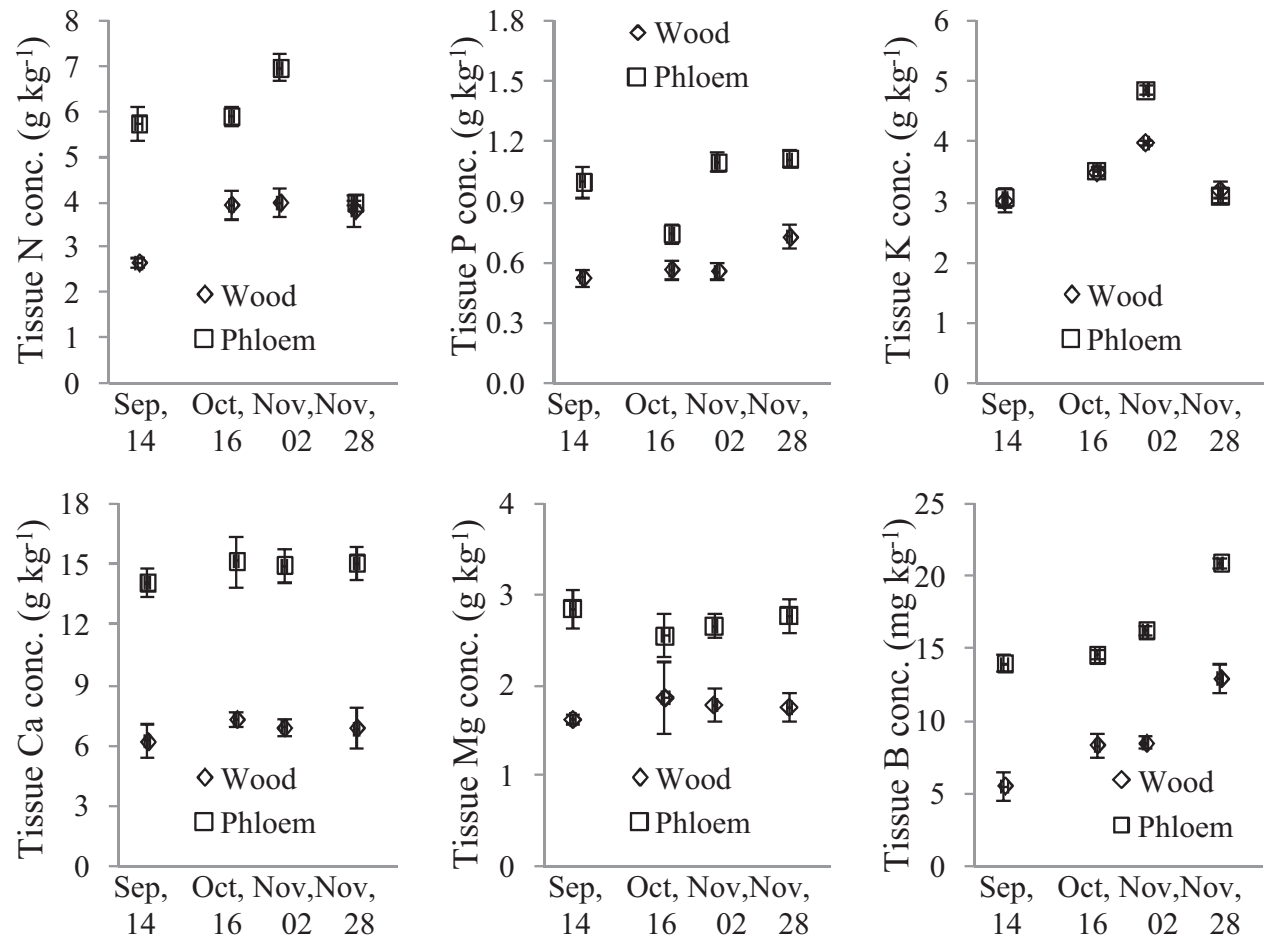

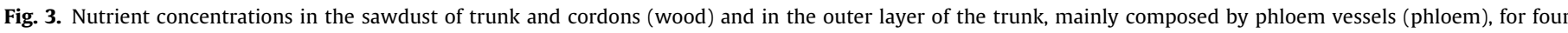
sampling dates from ripening, September 14th to late November 28th.

K concentrated tissues of the vine. The pulp presented a moderately high $\mathrm{K}$ concentration. The most plausible explanation for the high $\mathrm{K}$ concentration in the rachis is the role of the nutrient in the transportation of photosynthates from leaf to berry (Mpelasoka et al., 2003; Fogaça et al., 2007; Hawkesford et al., 2012). Nutrient concentrations in woody plant parts generally increased from trunk to cordons and canes, which mean that the older tissues are less concentrated in essential nutrients than the younger ones.

The clusters contained $19.9 \mathrm{~kg} \mathrm{~N}^{-1}$, representing $1.4 \mathrm{~kg} \mathrm{~N}$ per tonne of fresh fruit. On average, $\mathrm{N}$ removed per tonne of fruit was of similar magnitude to the values reported by Mullins et al. (2007). However, these are very low values ( 10\%) if compared to amounts of $\mathrm{N}$ usually removed by annual crops, such as maize and potato, which can amount to more than $200 \mathrm{~kg} \mathrm{~N} \mathrm{ha}^{-1}$ (Kirda et al., 2005; Badr et al., 2012). The amounts of the other nutrients removed in grape were 3.2, 28.7, 8.2 and $2.5 \mathrm{~kg} \mathrm{ha}^{-1}$ and $36.1 \mathrm{~g} \mathrm{ha}^{-1}$, respectively for $\mathrm{P}, \mathrm{K}, \mathrm{Ca}, \mathrm{Mg}$ and $\mathrm{B}$. The nutrients removed in the grape are an integral loss to the soil-plant system. About $50 \%$ of $\mathrm{N}$ $\left(41.7 \mathrm{~kg} \mathrm{ha}^{-1}\right)$ in the aboveground part of the vine was in the leaves at harvest time. Nitrogen in the leaves can be remobilized to the perennial parts and reused in the next season (White, 2012). Nitrogen can also be lost through volatilization directly from canopy to the atmosphere, in particular at the end of the growing season (Wetselaar and Farquhar, 1980; Eichert and Fernández, 2012). Nitrogen still present in the fallen leaves can suffer mineralization in the soil and be taken up by the roots or lost through $\mathrm{NH}_{3}$ volatilization, leaching or denitrification. Nitrogen present in canes $\left(7.7 \mathrm{~kg} \mathrm{ha}^{-1}\right)$ can follow the same routes if prunings are left on the ground. If prunings are removed their $\mathrm{N}$ is lost from the soil-plant system. Potassium plays a significant role in plant metabolism but it does not integrate organic structures (Hawkesford et al., 2012). Potassium present in leaves $\left(20.3 \mathrm{~kg} \mathrm{ha}^{-1}\right)$ can be remobilized to the perennial structure during senescence, due to its high mobility (Mpelasoka et al., 2003; Hawkesford et al., 2012). Other portion can be leached directly from the living leaves (Eichert and Fernández, 2012) or released to the soil during the mineralization of dead leaves. Potassium in the canes can also return or not to the soil depending on the destination of the prunings. Phosphorus, calcium, magnesium and boron present in the leaves and canes amounted to $5.4,68.8$ and $16.2 \mathrm{~kg} \mathrm{ha}^{-1}$ and $80.3 \mathrm{~g} \mathrm{ha}^{-1}$. These nutrients will return to the soil solution in the course of the mineralization of crop residues.

To follow the dynamic of the nutrients in the grapevine, tissues from different plant parts, collected at different time after grape harvest, were analyzed. The time of sampling was shown to affect leaf concentrations of all mineral elements. Nitrogen concentration in vine leaves usually decreases as the growing season progress (Porro et al., 1995; Peuke, 2009), likely due to dilution effects or remobilization to fruits and seeds. After harvest, plant growth is reduced or nil, and remobilizations to fruits ends. The decrease in leaf $\mathrm{N}$ concentration observed from September 14th to October 16th may be attributed to $\mathrm{N}$ remobilization to the perennial structures or to gaseous $\mathrm{N}$ losses to the atmosphere. The lower $\mathrm{N}$ concentration found in chlorotic leaves in comparison to green leaves, would be the result of the same phenomena. The increase in $\mathrm{N}$ concentration in canes and trunk and cordons observed from September 14th to November 2nd supports the thesis that at least part of the $\mathrm{N}$ present in leaves was remobilized to perennial structures. It is well-known that remobilization of nutrients from the leaves to woody parts is a typical feature of perennial species before leaf drop (White, 2012). Trunk and cordons showed a sudden decrease in $\mathrm{N}$ concentration from November 2 nd to November 28th, which may mean that $\mathrm{N}$ remobilization continued to the roots. Previous studies have shown that in grapevine, $\mathrm{N}$ reserves are located predominantly in the roots and are comprised of amino acids (mostly arginine) and proteins (Zapata et al., 2004) Phosphorus is a mobile element which can be readily translocated within a plant (Mullis et al., 2007; White, 2012). In vine leaves, P usually decreases over the growing season (Benito et al., 2013). The results of the temporal dynamic of $P$ in leaves showed a decrease in leaf $\mathrm{P}$ concentration from September 14th to October 16th and also between green leaves and chlorotic leaves. The woody plant parts, 
canes and trunk, showed minimum $\mathrm{P}$ concentration in October 16 th. These results seem to indicate possible remobilization of $P$ to roots occurred earlier in the autumn in comparison to the remobilization of $\mathrm{N}$.

Potassium is characterized by high mobility in plants at all levels, within individual cells or in long-distance transport via the xylem and phloem (Mpelasoka et al., 2003; White, 2012). Potassium concentration in the leaves did not change greatly between September 14th and October 26th. However, chlorotic leaves showed significantly lower $\mathrm{K}$ levels than green ones. Potassium concentration in canes and trunk increased from September 14th to October 16th and decreased from November 2nd to November 28th. In the trunk, K concentration increased from September 14th to November 2nd and deceased thereafter. This sequence of records seems to indicate a later remobilization of $\mathrm{K}$ from leaves to the woody parts in comparison to $\mathrm{N}$. A concurrent or complementary explanation for the low $\mathrm{K}$ concentration found in chorotic leaves is leaching from the canopy.

There was no great evidence that significant remobilization of $\mathrm{Ca}$ and $\mathrm{Mg}$ had occurred from the leaves to the woody plant parts. Chlorotic leaves had higher $\mathrm{Ca}$ and $\mathrm{Mg}$ concentrations than green ones. In the woody parts, the dynamic of $\mathrm{Ca}$ and $\mathrm{Mg}$ concentrations was also not relevant. The results likely reflect the low mobility in the phloem of both nutrients (White, 2012).

The reduction in leaf B concentration occurring from September 14 th to October 16 th was not confirmed by a reduction in B concentration in chlorotic leaves in comparison to green leaves. The analysis of the $\mathrm{B}$ in the woody parts showed an increase in $\mathrm{B}$ concentration from September 14th to November 28th. The mobility of B in plant tissues is generally considered as intermediate (White, 2012). However, it seems that B mobility greatly depends on plant species and cultivars (Brown and Shelp, 1997). Peuke (2009) reported changes in boron leaves similar to that observed to $\mathrm{N}$ during the growing season. Our results seem to confirm B mobility in grapevine in spite of a lack of B concentration measured in chlorotic leaves.

In a tentative estimation of the nutrient balance in a vineyard, nutrient removal from the system and nutrient recycling within the system should be taken into account. The vineyard lost $1.4 \mathrm{~kg} \mathrm{~N} \mathrm{ha}^{-1}$ per tonne of fresh fruit, representing a total of $\sim 20 \mathrm{~kg} \mathrm{Nha}^{-1}$ for this study. Starting from $\sim 42 \mathrm{~kg} \mathrm{Nha}^{-1}$ in the leaves at harvest, approximately $50 \%$ disappeared during senescence, which may mean that it was remobilized to the perennial structures and/or lost through volatilization from the canopy. The other half part ( $\left.\sim 21 \mathrm{~kg} \mathrm{~N} \mathrm{ha}^{-1}\right)$ was present in the fallen leaves. The fate of this $\mathrm{N}$ is very difficult to predict: it can be lost by ammonia volatilization if the leaves undergo mineralization at the soil surface and soil pH is high or, once in the soil, it can be lost by leaching or denitrification. The ground management of the vineyard may also be of great importance. Cover crops, for instance, can compete with the grapevine for the inorganic $\mathrm{N}$ in the soil (Celette et al., 2009; Celette and Gary, 2013) reducing the efficiency of $\mathrm{N}$ recycling. Nitrogen in the canes $\left(\sim 8 \mathrm{~kg} \mathrm{Nha}^{-1}\right)$ may have a similar destination to that referred to for leaves that mineralize in the soil or are lost if the prunings are removed from the vineyard.

The vineyard lost $28.7 \mathrm{~kg} \mathrm{~K} \mathrm{ha}^{-1}$ in the clusters. This amount represents $\sim 2.0 \mathrm{~kg} \mathrm{Kha}^{-1} \mathrm{yr}^{-1}$ per tonne of fresh fruit. If prunings are removed, the vineyard may lose another $\sim 11 \mathrm{~kg} \mathrm{Kha}^{-1}$. Potassium contained in the leaves will return to the soil, whether it is leached out from senescing leaves or released during the mineralization process in soil. Potassium does not undergo gaseous losses and the risk of $\mathrm{K}$ leaching from the soil is much less than that of $\mathrm{N}$. Thus, the component of recycling is easier to establish for $\mathrm{K}$ than for N. To establish an accurate $\mathrm{K}$ fertilization programme, it is also necessary to know the K availability in the soil and the K nutritional status of the vineyard, since any excess in $\mathrm{K}$ application should be avoided due to the negative impact in wine quality.

The amounts of $\mathrm{P}, \mathrm{Ca}$ and $\mathrm{Mg}$ removed from the system in clusters are small, and the nutrients contained in the leaves can be recycled in the soil. The recommendation system should involve monitoring soil fertility and plant nutritional status of vines in order to decide if any abnormal situation should be corrected. A regular addition of $\mathrm{P}, \mathrm{Ca}$ and $\mathrm{Mg}$ should not be needed.

The amount of B involved in plant metabolism is very small. However, there is a long experience of observing symptoms of $B$ deficiency in perennial crops, such as vine, almond and olive, in this region and in several other parts of the world. The recommendation system should consist of monitoring vine B nutritional status. Since $B$ is a mobile element in the soil, the application should be annual after it is proved that the soil does not supply enough $B$ for vine metabolism.

\section{Conclusions}

The establishment of a suitable fertilization programme for vineyards must consider different strategies for each individual nutrient. In the case of $\mathrm{N}$, it is of particular importance to take into account the amount of nutrient removed in the fruit as is currently done by most soil testing and plant analysis laboratories. This study showed that is also important to take into account the probable loss of $\mathrm{N}$ contained in leaves and canes at harvest, which may represent a loss greater than that from fruits, depending on how $\mathrm{N}$ is recycled within the agrosystem. For $\mathrm{K}$, it is not only important to consider the amount of nutrient removed in fruit, but also the amount of $\mathrm{K}$ naturally available in the soil, since soils can supply considerable amounts of K. Potassium in leaves is entirely recycled since the nutrient does not integrate in organic structures, which facilitates its leaching from leaves to the soil, and also because it does not form volatile compounds. Phosphorus, calcium and magnesium may not justify yearly applications, but probably only corrections in specific situations, relating to $\mathrm{pH}$ or low $\mathrm{P}$ availability in the soil, since nutrient removals are small. The amount of B involved in plant metabolism, and removed in fruits, is very small. However, B should be applied regularly, since it is a mobile element in the soil, but only after it has been diagnosed by plant analysis that the soil does not supply enough of this element for plant metabolism.

Thus, to establish an accurate fertilization programme, the decision-making process should have information on target yield and vineyard management strategies influencing the efficiency of use of nutrients present in leaves and canes. Data from soil testing and plant analysis continues to be of paramount importance. By integrating all sources of data it will be possible to prescribe fertilizer rates to ensure an adequate nutritional status of vines, without potentially detrimental effects on wine quality or environmental damage. In practice, for a rational use of fertilizers, nutrient-specific fertilization plans are needed.

\section{Acknowledgment}

Supported by the Mountain Centre (CIMO), Polytechnic Institute of Bragança, Portugal (PEst-OE/AGR/UI0690/2011 Strategic Project - UI 690 - 2011-2012).

\section{References}

Akin, A., Dardeniz, A., Ates, F., Celik, M., 2012. Effects of various crop loads and leaf fertilizer on grapevine yield and quality. J. Plant Nutr. 35, 1949-1957.

Amiri, M.E., Fallahi, E., 2007. Influence of mineral nutrients on growth, yield, berry quality, and petiole mineral nutrient concentrations of table grape. J. Plant Nutr. 30, 463-470. 
Assimakopoulou, A., Tsougrianis, C., 2012. Correlation between yield, must attributes and nutritional status of the greek red wine grape variety Agiorgitiko. J. Plant Nutr. 35, 1022-1036.

Badr, M.A., El-Tohamy, W.A., Zaghloul, A.M., 2012. Yield and water use efficiency of potato grown under different irrigation and nitrogen levels in an arid region. Agric. Water Manag. 110, 9-15.

Benito, A., Romero, I., Domínguez, N., García-Escudero, E., Martín, I., 2013. Leaf blade and petiole analysis for nutrient diagnosis in Vitis vinifera L. cv. Garnacha tinta. Aust. J. Grape Wine Res. 19, 285-298.

Beverly, R.B., Stark, J.C., Ojala, J.C., Embleton, T.W., 1984. Nutrient diagnosis of Valencia oranges by DRIS. J. Am. Soc. Hort. Sci. 109, 649-654.

Brown, P.H., Shelp, B.J., 1997. Boron mobility in plants. Plant Soil 193, 85-101.

Brunetto, G., Ceretta, C.A., Kaminski, J., Melo, G.W.B., Lourenzi, C.R., Furlanetto, V., Moraes, A., 2007. Application of nitrogen in grapevines in the campaign of the Rio Grande do Sul: productivity and chemical characteristics of the grape must. Cienc. Rural 37 (2), 389-393.

Celette, F., Gary, C., 2013. Dynamics of water and nitrogen stress along the grapevine cycle as affected by cover cropping. Eur. J. Agron. 45, 142-152.

Celette, F., Findeling, A., Gary, C., 2009. Competition for nitrogen in an unfertilized intercropping system: the case of an association of grapevine and grass cover in a Mediterranean climate. Eur. J. Agron. 30, 41-51.

Cuéllar, T., Azeem, F., Andrianteranagna, M., Pascaud, F., Verdeil, J.L., Sentenac, H., Zimmermann, S., Gaillard, I., 2013. Potassium transport in developing fleshy fruits: the grapevine inward $\mathrm{K}(+)$ channel VvK1.2 is activated by CIPK-CBL complexes and induced in ripening berry flesh cells. Plant J. 73, 1006-1018

Davenport, J.R., Lunden, J.D., Winkler, T., 2012. Wine grape tissue nutrient concentrations in the Inland Pacific Northwest. Commun. Soil Sci. Plant Anal. 43, 21-27

Eichert, T., Fernández, V., 2012. Uptake and release of elements by leaves and other aerial plant parts. In: Marschner, P. (Ed.), Marschner's Mineral Nutrition of Higher Plants. Academic Press, UK, pp. 71-84.

Fallahi, E., Shafii, B., Stark, J.C., Fallahi, B., Hafez, S.L., 2005. Influence of wine grape cultivars on growth and leaf blade and petiole mineral nutrients. HortTechnology 15 (4), 825-830.

Fogaça, A.O., Daudt, C.E., Dorneles, F., 2007. Potassium in grapes II - analysis of petioles and their correlation with the potassium content of wine grapes. Ciênc. Tecnol. Aliment. Campinas 27 (3), 597-601.

García-Escudero, E., Romero, I., Benito, A., Domínguez, N., Martín, I., 2013. Reference levels for leaf nutrient diagnosis of cv Tempranillo Grapevine in the Rioja appellation. Commun. Soil Sci. Plant Anal. 44, 645-654.

Gilbert, N., 2009. The disappearing nutrient. Nature 461, 716-718.

Goh, K.M., Malakouti, M.J., 1992. Preliminary nitrogen, phosphorus, potassium, calcium and magnesium DRIS norms and indices for apple orchards in Canterbury, New Zealand. Commun. Soil Sci. Plant Anal. 23, 1371-1385.

Havlin, J.L., Beaton, J.D., Tisdale, S.L., Nelson, W.L., 2005. Soil Fertility and Fertilizers: An Introduction to Nutrient Management, 7th ed. Pearson Prentice Hall, New Jersey, pp. 515.

Hawkesford, M., Horst, W., Kichey, T., Lambers, H., Schjoerring, J., Møller, I.S., White, P., 2012. Functions of macronutrients. In: Marschner, P. (Ed.), Marschner's Mineral Nutrition of Higher Plants. Academic Press, UK, pp. 135-189.

Kirda, C., Topcu, S., Kaman, H., Ulger, A.C., Yazici, A., Cetin, M., Derici, M.R., 2005. Grain yield response and $\mathrm{N}$-fertiliser recovery of maize under deficit irrigation. Field Crop Res. 93, 132-141.
Lehoczky, E., Kocsis, L., 1998. Nutrient content of grapevine leaves in various graft combinations. Commun. Soil Sci. Plant Anal. 29 (11-14), 1983-1989.

Mackay, D.C., Carefoot, J.M., Entz, T., 1987. Evaluation of the DRIS procedure for assessing the nutritional status of potato (Solanum tuberosum L.). Commun. Soil Sci. Plant Anal. 18 (12), 1331-1353.

Martín, I., Benito, A., Romero, I., Domínguez, N., García-Escudero, E., 2013. Preliminary diagnosis and recommendation integrated system norms for leaf nutrient diagnosis of Tempranillo grapevine in the Rioja appellation. Commun. Soil Sci. Plant Anal. 44, 655-667.

Mills, H.A., Jones Jr., J.B., 1996. Plant Analysis Handbook II. MicroMacro publishing, Athens, GA, pp. 422p.

Mpelasoka, B.S., Schachtman, D.P., Treeby, M.T., Thomas, M.R., 2003. A review of potassium nutrition in grapevines with special emphasis on berry accumulation. Aust. J. Grape Wine Res. 9, 154-168.

Mullins, M.G., Bouquet, A., Williams, L.E., 2007. Biology of the Grapevine. University Press, Cambridge, UK, pp. 239p.

Pérez-Álvarez, E.P., Martínez-Vidaurre, J.M., Martín, I., García-Escudero, E., Peregrina, F., 2013. Relationships among soil nitrate nitrogen and nitrogen nutritional status, yield components, and must quality in semi-arid vineyards from Rioja AOC, Spain. Commun. Soil Sci. Plant Anal. 44, 232-242.

Peuke, A.D., 2009. Nutrient composition of leaves and fruit juice of grapevine as affected by soil and nitrogen fertilization. J. Plant Nutr. Soil Sci. 172, 557-564.

Poni, S., Quartieri, M., Tagliavini, M., 2003. Potassium nutrition of Cabernet Sauvignon grapevines (Vitis vinifera L.) as affected by shoot trimming. Plant Soil 253 , $341-351$.

Porro, D., Stefanini, M., Failla, O., Stringari, G., 1995. Optimal leaf sampling time in diagnosis of grapevine nutritional status. Acta Hort. 383, 135-142.

Porro, D., Stringari, G., Failla, O., Scienza, A., 2001. Thirteen years of leaf analysis applied to Italian viticulture. Acta Hort. 564, 413-420.

Powlson, D.S., 1993. Understanding the soil nitrogen cycle. Soil Use Manag. 9 (3) 86-94.

Römheld, V., 2012. Diagnosis of deficiency and toxicity of nutrients. In: Marschner P. (Ed.), Marschner's Mineral Nutrition of Higher Plants. Academic Press, UK, pp. 299-312.

Smil, V., 2001. Enriching the Earth: Fritz Haber, Carl Bosch, and the Transformation of World Food Production. Massachusetts Institute of Technology, Massachusettes, USA, pp. 338.

Summer, M.E., 1997. Application of beufils diagnostic indices to maize data published in the literature irrespective of age and conditions. Plant Soil 46, 359-369.

Walinga, I., van Vark, W., Houba, V.J.G., van der Lee, J.J., 1989. Soil and Plant Analysis. Part 7 - Plant Analysis Procedures. Wageningen Agricultural University, The Netherlands, pp. 263p.

Wetselaar, R., Farquhar, G.D., 1980. Nitrogen losses from tops of plants. Adv. Agron. 33, 263-302.

White, P., 2012. Long-distance transport in the xylem and phloem. In: Marschner, P. (Ed.), Marschner's Mineral Nutrition of Higher Plants. Academic Press, UK, pp. 49-70.

Winkler, A.J., Cook, J.A., Kliewer, W.M., Lider, L.A., 1974. General Viticulture. Univ. California Press, USA, pp. 710-719.

Zapata, C., Deléens, E., Chaillou, S., Magné, C., 2004. Partitioning and mobilization of starch and $\mathrm{N}$ reserves in grapevine (Vitis vinifera L). J. Plant Physiol. 161, 1031-1040. 